\title{
IRIS SIBIRICA HAS UNUSUAL, PRACTICALLY NON-DIFFERENT HEAT TOLERANCE OF PS II AT DIFFERENT GEOGRAPHICAL EXPOSURES ON THE BÜKK-PLATEAU (NORTH-HUNGARY)
}

\section{Sándor Dulai 1*, Réka Tarnai', Dóra Szopkó1, Anna E-Vojtkó2, Dóra Salamon' ${ }^{1}$ Ammar Allem ${ }^{3}$ \& András Vojtkó ${ }^{1}$}

${ }^{1}$ Eszterházy Károly University, Department of Botany and Plant Physiology, $\mathrm{H}$ 3300 Eger, Leányka u. 6, Hungary; ${ }^{2}$ Department of Botany, University of South Bohemia, České Budějovice, Czechia; ${ }^{3}$ Biological Doctoral School, St. Stephen University, H-2011 Gödöllö, Hungary; *E-mail: dulai.sandor@uni-eszterhazy.hu

\begin{abstract}
Heat tolerance of photosystem II (PSII) was examined in Siberian flag (Iris sibirica L.) living in different microhabitats of a non-forested enclosed depression surface (doline) on the Bükk-plateau. Although the microclimatic parameters of the habitats with different facing sites show sharp contrasts, there was no significant difference between the heat tolerance of PSII in leaves of $I$. sibirica growing in these expositions neither in dark- nor in light-adapted state.
\end{abstract}

Keywords: Iris sibirica, heat tolerance, photosynthesis, microhabitat

\section{INTRODUCTION}

Doline vegetation is influenced by a number of factors including altitude and significant differences in microclimate or soil moisture along slopes with given exposures. Due to the zone inversion parallel to climate change, montane species are already present on the bottom and northern slopes, while on southern slopes, species that favor drier and warmer climates are common (Bátori et al. 2014). However, some species occur in both aspects of the doline despite significant differences in air temperature, air and soil humidity, which requires special adaptation/acclimation strategies, especially against the temperature. In this paper, we present some preliminary results on the unusual, practically non-different heat tolerance of I. sibirica growing in different exposures. 


\section{MATERIALS AND METHODS}

Leaves of Siberian flag (Iris sibirica L.) were collected from five different geographical exposition (bottom, N/S facing slopes, and $\mathrm{N} / \mathrm{S}$ edge) of the second biggest non-forested doline in the Bükkplateau (North-Hungary) between six and seven am. The collected leaves were immediately wrapped in wet filter paper and transported to the laboratory within half an hour. The in vivo heat induced chlorophyll $a$ fluorescence was measured in dark- and light-adapted state of leaves with a pulse amplitude modulated fluorometer (IMAGING PAM M-series, Walz, Effeltrich, Germany). The leaves were dark-adapted for $30 \mathrm{~min}$, and then placed on the thermoelectric module. The minimum chlorophyll fluorescence $\left(F_{0}\right)$ was monitored in leaf discs exposed to elevated temperature from $25^{\circ} \mathrm{C}$ to $49-55^{\circ} \mathrm{C}$ at a rate of $1^{\circ} \mathrm{C} \mathrm{min}^{-1}$. Recording of the steady-state fluorescence $\left(F_{s}\right) v$. $T$ curves started when the photosynthesis was steady at 200 and $1,000 \mu \mathrm{mol} \mathrm{m}^{-2} \mathrm{~s}^{-1}$ actinic light intensity. Critical temperature $\left(T_{\mathrm{c}}\right)$ values were determined as the interception of regression lines fitted to $F_{0}$ and $F_{\mathrm{s}}$ data.

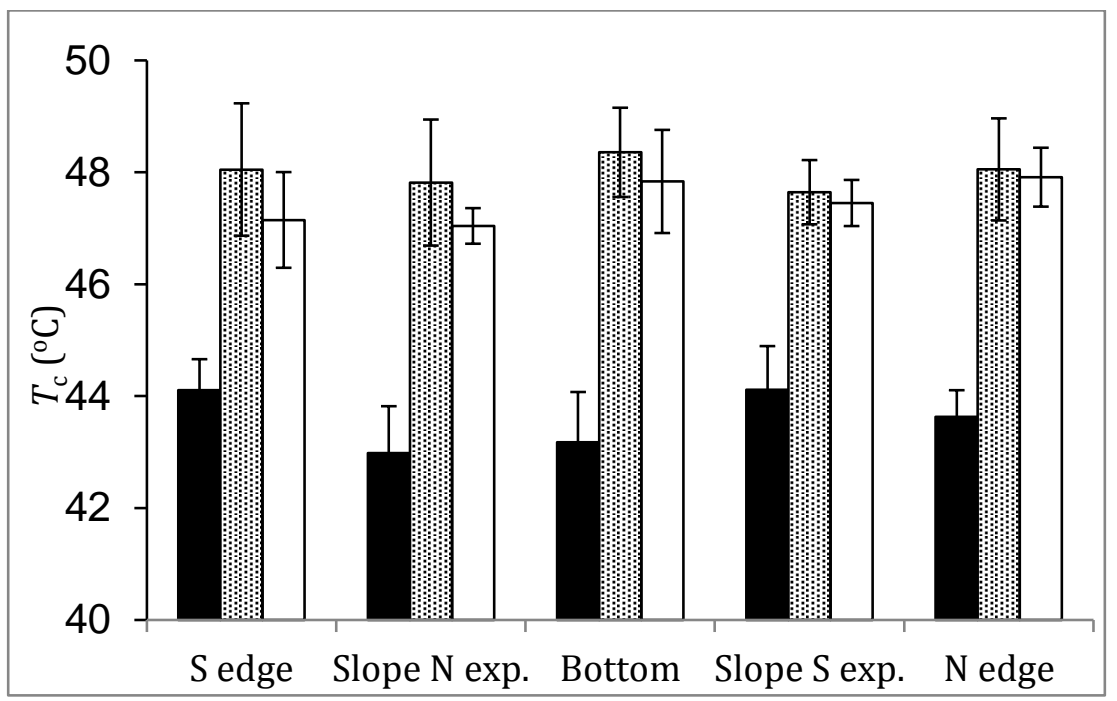

Figure 1. Critical temperature $\left(T_{\mathrm{c}}\right)$ values of $F_{0}$ (filled bars) and $F_{\mathrm{s}} v . T$ curves at

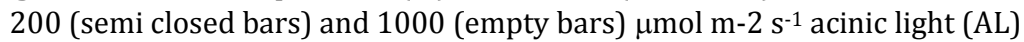
intensities in leaves of Iris sibirica growing in different facing parts of the doline. 


\section{RESULTS AND DISCUSSION}

The heat sensitivity of the photosynthetic apparatus is closely connected to the thermal stability of PSII, which is well characterised by critical values of the temperature dependence of the initial fluorescence $\left(F_{0}\right)$ level in dark-adapted leaves (Dulai et al. 1998, Szopkó and Dulai 2018). There was no significant difference in the heat tolerance of PSII determined by the $T_{\mathrm{c}}$ values of the $F_{0} \mathrm{~V}$. $T$ curves (recorded practically in darkness) in leaves of $I$. sibirica living in different expositions and it was not sufficient for tolerating such high temperatures that are peculiar to the microhabitat of $S$ facing slope above the surface (Figure 1). Similarly to $F_{0}$, the breakpoints $\left(T_{\mathrm{c}}\right)$ of temperature dependence of steady state fluorescence $\left(F_{\mathrm{s}}\right)$ appropriately show the thermal stability of samples at steady-state photosynthesis level in light adapted state (Molnár et al. 1998). In connection with this, $T_{\mathrm{c}}$ values of $F_{\mathrm{s}} v . T$ curves measured at 200 and $1000 \mu \mathrm{E} \mathrm{m}^{-2} \mathrm{~s}^{-1}$ actinic light intensity are shifted towards significantly higher temperatures $\left(\sim 47-48{ }^{\circ} \mathrm{C}\right)$, indicating the higher thermal tolerance of PSII (Figure 1). This is consistent with those observations that light stimulates the thermal stability of the PSII (Molnár et al. 1998, Dulai et al. 2006). However, ground level air temperatures on the S-facing slope can often exceed $47-48{ }^{\circ} \mathrm{C}$ with extreme daily fluctuations. So this reduced heat sensitivity is just enough to tolerate the high temperature conditions of the S-facing slope during the daytime period of a summer day. At the same time, the doline micro-habitats with different exposures are characterized by sharp and significant microclimatic variation (Bátori et al. 2019). These differences are manifested not only in the average daily means of ground level air temperature but also in daily maxima, daily range and air and soil moisture. As a result, more cool-adapted plants are found on the north-facing slopes and bottoms of dolines (Bátori et al. 2017). However, some species, like Siberian flag, occur in both aspects of the depression despite the above mentioned differences in environmental factors, which should require a very plastic phenotypic performance to temperature conditions. This would also require optimizing the heat stability of the photosynthetic apparatus according to the factors specific to the given exposure. Thus, it is very unusual for a plant to occur in all micro-habitats of 
the doline but not to be able to change its temperature tolerance neither in dark- nor in light-adapted state. Consequently, as the forecasted climatic extremities increase, this plant might disappear completely from the southern slope.

Acknowledgement - The first author's research was supported by the grant EFOP-3.6.1-16-2016-00001 ("Complex improvement of research capacities and services at Eszterházy Károly University").

\section{REFERENCES}

BÁtori, Z., E-VojtKó, A., ERDős, L. \& VojtKó, A. (2014). Temperature and soil moisture regimes of the forested and non-forested dolines of the Bükk Mountains based on ecological indicator values (in Hungarian). Kitaibelia 19: 331-338.

Bátori, Z., VojtKó, A., MaÁk, I.E., LőRinczi,, G., FARKAS, T., Kántor, N., TANács, E., Kiss, P.J., Juhász, O., Módra, G., Tölgyesi, Cs., ERdős, L., Aguilon, D.J. \& Keppel, G. (2019). Karst dolines provide diverse microhabitats for different functional groups in multiple phyla. Nature Scientific Reports 9: 1-13. 7176.

https://doi.org/10.1038/s41598-019-43603-X

Bátori, Z., VojtKó, A., Farkas, T., Szabó, A., HavadtőI, K., E-VojtKó, A., Tölgyesi, Cs., CSEH, V., ERDŐS, L., MAÁK, I.E. \& KePPEL, G. (2017). Large- and small-scale environmental factors drive distributions of cool-adapted plants in karstic microrefugia. Annals of Botany 119: 301-309.

http://dx.doi.org/10.1093/aob/mcw233

DulAI, S., MolnÁR, I. \& LEHOCZKI, E. (1998). Effects of growth temperature of 5 and 25 ${ }^{\circ} \mathrm{C}$ on long-term responses of photosystem II to heat stress in atrazineresistant and susceptible biotypes of Erigeron canadensis (L.). Australian Journal of Plant Physiology 25: 145-153. https://doi.org/10.1071/PP97112

Dulai, S., Molnár, I., Prónay, J., Csernák, Á., Tarnai, R. \& Molnár-Láng, M. (2006). Effects of drought on photosynthetic parameters and heat stability of PSII in wheat and in Aegilops species originating from dry habitats. Acta Biologica Szegediensis 50: 11-17.

Molnár, I., CsizI, K., Dulai, S., Darkó, É. \& LeHoczKI, E. (1998). Light dependence of thermostability of photosynthetic apparatus. In: GARAB, G. (ed.): Photosynthesis: Mechanisms and Effects. Kluwer Academic Publishers, Dordrecht, pp. 22412244. https://doi.org/10.1007/978-94-011-3953-3_524

SzopKó, D. \& DuLAI, S. (2018). Environmental factors affecting the heat stability of the photosynthetic apparatus. Acta Biologica Plantarum Agriensis 6: 90-107. https://doi.org/10.21406/abpa.2018.6.90

(submitted: 17.03.2020, accepted: 24.04.2020) 